\title{
Performance Analysis of Mobile Banking During the COVID-19 Pandemic Period Comparing with the Pre-pandemic Period of Covid- 19: An Empirical Study on Bangladesh
}

\author{
Md. Ruhul Amin ${ }^{1}$, Md. Nahiduzzaman ${ }^{2}$ \\ ${ }^{1,2}$ Department of Finance and Banking, Islamic University, Bangladesh
}

\section{ABSTRACT}

Objective - Mobile banking is a growing activity to engage the non-banking people in the banking system in Bangladesh, so researchers of this paper try to find out how much it is affected by the Coronavirus (COVID-19). Basically, this study is developed to assess the performance of mobile banking during the COVID-19 pandemic period comparing with the pre-pandemic period.

Methodology/Technique - Authors use descriptive statistics to evaluate the performance of mobile bank during the study period from 2014 to August 2020.

Findings - This paper finds that during the COVID period the average change of monthly number of active accounts $\&$ registered clients have increased, on the other hand the average change of monthly number of agents have decreased at the same time. Except cash in \& cash out, all other types of transactions proportion of mobile banking have increased during the COVID-19 period.

Novelty - As the mobile banking is a key resource for banking people as well as non-banking people to transact financial things at setting at the house, so this paper will be beneficial for mobile banking service provider organization to assess the whole things of mobile banking at this ongoing period, and they can take necessary action.

Type of Paper: Empirical.

JEL Classification: G21, G22.

Keywords: Mobile Banking, COVID-19, Financial Performance, Bangladesh.

Reference to this paper should be referred to as follows: Amin, M.R; Nahiduzzaman, M. (2021). Performance Analysis of Mobile Banking During the COVID-19 Pandemic Period Comparing with the Pre-pandemic Period of Covid-19: An Empirical Study on Bangladesh, Acc. Fin. Review,6(1), 54 - 68. https://doi.org/10.35609/afr.2021.6.1(2)

\section{Introduction}

Mobile! It is a common word for people and banking system is trying to get familiar with their existence in front of people by using this word. Right now, the world is experiencing a pandemic period (Covid-19 period) that's why people cannot move anywhere for doing money related activities. So, they are always searching for a comfortable way so that they can meet their daily financial requirements. Mobile banking is the way by which people can use it setting at the room or at anywhere else whatever they are in now.

\footnotetext{
* Paper info: Revised: April 10, 2021

Accepted: June 30, 2021

* Corresponding author: Md. Ruhul Amin

E-mail: ruhul1112003@yahoo.com

Affiliation: Department of Finance and Banking, Islamic University, Bangladesh
} 
During the COVID-19 period its daily uses are increasing day by day because of isolation \& home quarantine system and lockdown of the country. According to the FINCA news (2020) uses of mobile banking in USA have increased $85 \%$ during the COVID-19 period and similarly for other countries. During the pandemic period, clients of physical banking is shifting to the virtual banking mode, mostly to mobile banking. In USA many banks are launching virtual banking systems for their customers (Iyar, 2020). In a recent research study on China and Italy, shifting of customers to the digital platforms has increased 10\% to $20 \%$ (Skalska, 2020). According to monetary authority of Hong Kong, using rate of mobile banking in Hong Kong rose during the COVID-19 period (Yue, 2020). In the part of virtual banking, many banksare trying to link their services to the mobile banking system by which customers of these banks can transfer their funds to mobile banking. In this pandemic period, Social Islami Bank Limited (SIBL) in Bangladesh is requesting their customers to use bank apps and not to frequently visit branch for any needs. They provide various types of facilities through this app so that customers of this bank can top up their funds to Bkash and they can provide payment to the various sector like Desco, utility bill payments of Dpdc, Titas, Wasa and many others (Report, 2020). All things are facilitating mobile banking because these banking systems are easy to work with online.

In perspective of Bangladesh MFSs was started by Dutch-Bangla Bank Limited (DBBL) in 2012 but the full fledge operation took another two years. Currently 28 banks have a license to offer MFS and many institutions are waiting for authorization, even though 28 institutions have licenses, 15 are providing the services (Bangladesh Bank, 2020). These banks are providing the different services throughout the country depicted in the figure 1.

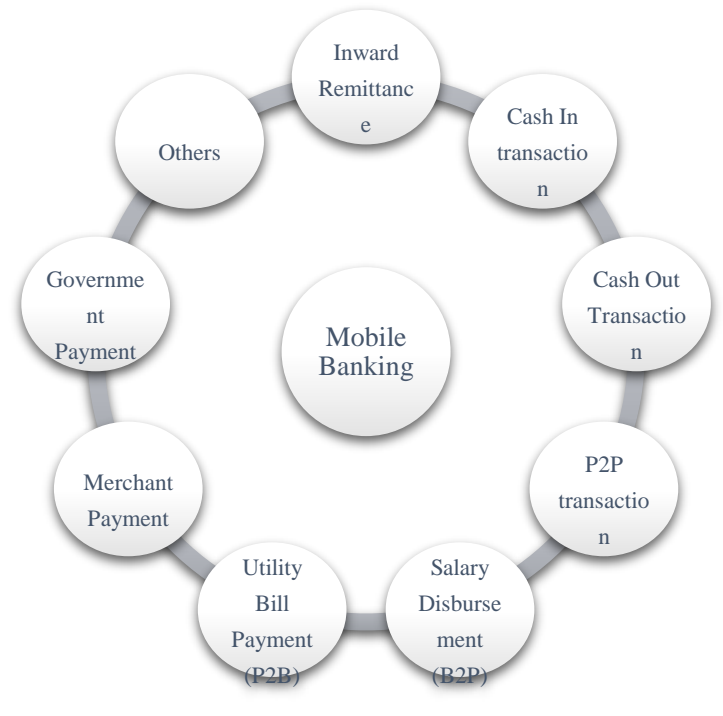

Figure 1: Banks Services

This paper is unique in nature with regards to its present situation in the world. There are many studies undertaken in Bangladesh as well as in the world on Mobile Banking like financial inclusion through $\mathrm{m}$ banking, consumer behaviors towards m-banking, performance measurement of m-banking at different perspectives, impact of $\mathrm{m}$-banking on commercial bank's performance, preference perception of m-banking, prospects and challenges of $m$-banking, role of $m$-banking in case of enhancing financial performance, perceived risk of m-banking. But thus far, no paper has discussed the performance of mobile banking during the COVID-19 pandemic period compared with the pre-pandemic period. The researchers of this paper have tried to add some effective information to the economy of Bangladesh and world about the current situation of mobile banking which serve the current demand. 
This paper aims at achieving various types of objectives which mobile banking providers are able to offer their banking customers and people in the country, in general. Three objectives are listed below:

To represent the present status of mobile banking in Bangladesh.

To measure the performance of mobile banking during the COVID-19 pandemic period and pre-pandemic period.

To compare the performance of mobile banking between pre-pandemic period and pandemic period.

\section{Literature Review}

(Kato, G. K., Otuya, W. I., Owunza, J. D. Nato, 2015) Conducted research on "Mobile Banking and Performance of Commercial Banks in Kenya". They evaluate the relationship between mobile bank \& commercial bank's performance and measure its effect on the adoption of mobile banking in Kenya. The authors consider customers perception about banks, attitudes on mobile banking and its effect on the performance of mobile bank and commercial bank through questionnaires distributed to the customers \& operation staffs. This paper has used Pearson's correlation model and regression analysis to examine the data. The authors disclosed that the performance of commercial bank and mobile banking are positively correlated to each other. They found that customers perception towards the mobile bank has increased depending on positive performance of commercial bank.

(Atieno, 2018): Researched on "Mobile Banking and Organizational Performance in the Banking Industry". They try to explore how some factors of mobile banking affect the organizational and banking industry performance in Kenya. They focus on the transactional security, delivery speed of services and cost of operation as indicator for measurement of the performance. Authors collect primary data through different types of questionnaires from the employees and customers of the bank and use descriptive statistical tools like Likert scale for measurement of the desired result. The authors' finding shows that there is a positive relationship between mobile banking and performance of banking organization. The authors conclude that financial performance of banking sector is influenced by mobile banking.

(Khan, Akter, \& Akter, 2017): Studied "Factors Influencing Adoption and Usage of Mobile Banking: Bangladesh Experience". They explore the factors which affect the adoption and usages of mobile banking in Bangladesh. They consider trustworthiness, complexity, security, network availability and cost and convenience influencing factor for measuring the perception towards mobile banking which may think of a customer when he/she is going to adopt mobile banking services. They take 400 mobile banking users as sample of the study over a 4-year period. This paper is analyzed by descriptive statistics like mean, median, mode, standard deviation, linear regression model and hypothesis formulation. Authors find that demographic characteristics, trustworthiness \& network problems do not influence the adoption of mobile banking on the other hand security, complexity \& cost and convenience of using mobile banking affect the adoption of mobile banking service.(Hossain \& Haque, 2014)

(Sagib \& Zapan, 2014): Investigated "Bangladeshi mobile banking service quality and customer satisfaction and loyalty". They attempt to investigate the various services quality of mobile banks and its impact on the customer satisfaction. Authors select efficiency \& convenience, assurance \& security, reliability \& responsiveness and locational advantage as the perception measurement tools of $\mathrm{m}$-banking customers. This paper analyses collected information through regression analysis and finds that only the service quality is the prerequisite of $\mathrm{m}$-banking organization for customer attraction and after that reliability \& responsiveness and efficiency \& convenience impact positive influence on customer satisfaction. The authors also find that efficiency \& reliability helps to retain the mobile banking customers in the long run.

(G., V, Sathish. M, \& A.V, 2020): Drafted a paper on "Impact of COVID-19 Outbreak in Digital Payments". They disclose how a COVID-19 pandemic situation affects the various types of digital payment systems in India. They demonstrate buying and payment behavior of customers during the lockdown period 
and pre-lockdown period. The authors of this study collect information from primary and secondary sources and use T-test, Chi-square test and ANOVA test for analysis data to obtain the results of the study. They find that there are significant differences between mode of payment during the lockdown period and prelockdown period but there is no significant difference between these times in case of groceries products, vegetables, hotels, transport mode of payment system.(Al-Husein \& Sadi, 2015).

(Bidarra \& Henrique, 2013), (Muiruri, 2015), (Rehman \& Shaikh, 2020), (Shuhidan et al., 2017), (Siddik et al., 2016), (Abuga, I. M., \& Manyange, 2015), (Bach et al., 2020), (Krishna Kishore \& Sequeira, 2016), (Sagib \& Zapan, 2014), (Saleem \& Rashid, 2011), (Too et al., 2016), (Arifin, 2018), (Tafese \& Desta, 2014).

\section{Methodology}

This study is analyzed based on the secondary data which has been taken mainly from Bangladesh bank website, various types of journals, magazines, reports and websites. For completion of the report descriptive statistical tools are used to measure the performance of mobile bank for the last 7 years (2014 to August 2020) at the pre-pandemic period of COVID-19 and COVID-19 period as well. Among the descriptive tools, hypothetical analysis, percentile changes, graphical representation are used here. Descriptive statistics of number of agents, number of clients and number of active customers demonstrate how much change these respective data over the study period. ANOVA test clarifies is any significant difference among prepandemic period of COVID-19, pandemic period, and previous respective month to pandemic period of agents, clients, and number of active customers. T-test identifies during the COVID-19 period the above data is changed or not. Percentage calculation and graphical representation is used for interpreting other types of mobile banking data which are changed during the COVID-19 period compared with the pre-pandemic period of COVID-19.

Time period for hypothesis analysis

\begin{tabular}{|c|c|c|c|}
\hline \multirow{3}{*}{$\begin{array}{c}\text { ANOVA } \\
\text { (F-Test) }\end{array}$} & Pre-pandemic period of Covid-19 & Month & Jan, Feb, Mar, Sep, Oct, Nov, Dec \\
\cline { 2 - 4 } H1, H2, & & Year & 2014, 2015, 2016, 2017, 2018, 2019, 2020 \\
\cline { 2 - 4 } H3 & Pandemic Period & Month & Apr, May, June, Jul, Aug \\
\cline { 2 - 4 } & & Year & 2020 \\
\cline { 2 - 4 } & $\begin{array}{c}\text { Previous respective month to } \\
\text { pandemic period }\end{array}$ & Month & Apr, May, June, Jul, Aug \\
\cline { 2 - 4 } (T-Test) & Pre-pandemic period of Covid-19 & Year & 2014, 2015, 2016, 2017, 2018, 2019 \\
H4, H5, & & & Jan, Feb, Mar, Apr, May, Jun, Jul, Aug, Sep, Oct, \\
H6 & & Year & 2014, 2015, 2016, 2017, 2018, 2019, 2020 \\
\cline { 2 - 4 } & Pandemic Period & Month & Apr, May, June, Jul, Aug \\
\cline { 2 - 4 } & & Year & 2020 \\
\hline
\end{tabular}

Author's own concern

The Following formulas are used for the T-test.

Sample standard deviation, $\mathrm{S}=\sqrt{\frac{\sum(x-\bar{x})^{2}}{n}}$

Standard error, $\overline{x_{1}}-\overline{x_{2}}=\left(\mu_{1}-\mu_{2}\right) H_{0} \pm \operatorname{TSP} \sqrt{\frac{1}{n_{1}}}+\sqrt{\frac{1}{n_{2}}}$

Here, $\mathrm{SP}=\sqrt{\frac{\left(n_{1}-1\right) S_{1}^{2}+\left(n_{2}-1\right) S_{2}^{2}}{n_{1}+n_{2}-2}}$
Here, $x=$ Principal Value

$n_{1}=$ Number of Sample-1

$n_{2}=$ Number of Sample- 2

$s_{1}=$ Sample- 1 Standard Deviation

$s_{2}=$ Sample-2 Standard Deviation 
Value of $\mathrm{T}=\frac{\left(\overline{x_{1}}-\overline{x_{2}}\right)-\left(\mu_{1}-\mu_{2}\right) H_{0}}{\operatorname{sP} \sqrt{\frac{1}{n_{1}}}+\sqrt{\frac{1}{n_{2}}}}$

The Following formulas are used for the F (ANOVA)-test

Between column variance $\hat{\sigma} b^{2}=\frac{\sum n j(\bar{x} j-\bar{x})^{2}}{k-1}$

Within column variance $\hat{\sigma} w^{2}=\sum\left(\frac{n j-1}{n T-k}\right) s^{2} j$

For hypothesis analysis, the following hypotheses have been built for accomplishment of the objectives of this research paper.

\section{Hypotheses of the Study}

H1: There is significant difference between changes in the numbers of active customers among prepandemic period, pandemic period and previous respective months to pandemic period of COVID-19.

$\mathrm{H} 2$ : There is significant difference between changes in the numbers of clients among pre-pandemic period, pandemic period and previous respective months to pandemic period of COVID-19.

H3: There is significant difference between changes in the numbers of agents among pre-pandemic period, pandemic period and previous respective months to pandemic period of COVID-19.

H4: The changes in the number of active customers are increased during the COVID-19 pandemic period.

H5: The changes in the numbers of clients are increased during the COVID-19 pandemic period.

H6: The changes in the numbers of agents are increased during the COVID-19 pandemic period.

\section{Results}

\section{Descriptive Statistics}

Table 1: Change in Average monthly number of active accounts per year (Amount Figure in Lac)

\begin{tabular}{|c|c|c|c|c|c|c|c|c|c|}
\hline \multirow{2}{*}{\multicolumn{2}{|c|}{ Description }} & \multicolumn{8}{|c|}{ Statistic } \\
\hline & & 2014 & 2015 & 2016 & 2017 & 2018 & 2019 & $\begin{array}{l}2020 \text { till } \\
\text { March }\end{array}$ & $\begin{array}{l}2020 \text { Apr } \\
\text { to Aug }\end{array}$ \\
\hline \multicolumn{2}{|c|}{ Mean } & 4.650 & 0.887 & 2.213 & 4.272 & 13.603 & -2.231 & -26.003 & 27.456 \\
\hline \multirow{2}{*}{$\begin{array}{c}95 \% \\
\text { Confidence } \\
\text { Interval for } \\
\text { Mean }\end{array}$} & $\begin{array}{l}\text { Lower } \\
\text { Bound }\end{array}$ & -0.472 & -6.169 & -1.362 & -18.877 & 1.695 & -21.821 & -104.809 & -16.068 \\
\hline & $\begin{array}{l}\text { Upper } \\
\text { Bound }\end{array}$ & 9.772 & 7.943 & 5.788 & 27.420 & 25.510 & 17.360 & 52.803 & 70.980 \\
\hline \multicolumn{2}{|c|}{$5 \%$ Trimmed Mean } & 5.337 & 1.094 & 2.201 & 3.332 & 13.267 & -2.869 & & 27.582 \\
\hline \multicolumn{2}{|c|}{ Median } & 6.940 & 1.760 & 2.270 & 6.470 & 11.715 & -2.550 & -13.520 & 31.100 \\
\hline \multicolumn{2}{|c|}{ Variance } & 58.134 & 123.331 & 31.661 & 1327.398 & 351.210 & 950.679 & 1006.406 & 1228.710 \\
\hline \multicolumn{2}{|c|}{ Std. Deviation } & 7.625 & 11.105 & 5.627 & 36.433 & 18.741 & 30.833 & 31.724 & 35.053 \\
\hline \multicolumn{2}{|c|}{ Minimum } & -14.580 & -23.600 & -8.850 & -48.570 & -9.720 & -53.780 & -62.070 & -21.050 \\
\hline \multicolumn{2}{|c|}{ Maximum } & 11.510 & 21.640 & 13.500 & 74.020 & 42.960 & 60.810 & -2.420 & 73.700 \\
\hline \multicolumn{2}{|c|}{ Range } & 26.090 & 45.240 & 22.350 & 122.590 & 52.680 & 114.590 & 59.650 & 94.750 \\
\hline \multicolumn{2}{|c|}{ Interquartile Range } & 8.420 & 9.243 & 4.673 & 41.558 & 37.923 & 39.715 & . & 61.680 \\
\hline
\end{tabular}

Note: April to August in 2020 is the COVID-19 pandemic period: Table 2

\begin{tabular}{|l|l|l|l|l|l|l|l|l|}
\hline Data & N & Mean & Std. & Std. & $95 \%$ Confidence & Minimu & Maximu & Between- \\
\hline
\end{tabular}




\begin{tabular}{|c|c|c|c|c|c|c|c|c|c|c|}
\hline & & & \multirow[t]{2}{*}{ Deviation } & \multirow[t]{2}{*}{ Error } & \multicolumn{2}{|c|}{ Interval for Mean } & \multirow[t]{2}{*}{$\mathrm{m}$} & \multirow[t]{2}{*}{$\mathrm{m}$} & \multirow{2}{*}{$\begin{array}{c}\text { Component } \\
\text { Variance }\end{array}$} \\
\hline & & & & & & $\begin{array}{l}\text { Lower } \\
\text { Bound }\end{array}$ & $\begin{array}{l}\text { Upper } \\
\text { Bound }\end{array}$ & & & \\
\hline \multicolumn{2}{|c|}{$\begin{array}{l}\text { Pre-pandemic } \\
\text { period }\end{array}$} & 44 & 0.693 & 23.988 & 3.616 & -6.600 & 7.986 & -62.070 & 74.020 & 44.000 \\
\hline \multicolumn{2}{|c|}{ Pandemic period } & 5 & 27.456 & 35.053 & 15.676 & -16.068 & 70.980 & -21.050 & 73.700 & 5.000 \\
\hline \multicolumn{2}{|c|}{$\begin{array}{c}\text { Previous } \\
\text { respective month } \\
\text { to pandemic } \\
\text { period }\end{array}$} & 30 & 5.586 & 20.640 & 3.768 & -2.121 & 13.293 & -40.960 & 59.540 & 30.000 \\
\hline \multicolumn{2}{|c|}{ Total } & 79 & 4.245 & 24.103 & 2.712 & -1.154 & 9.644 & -62.070 & 74.020 & 79.000 \\
\hline \multirow[t]{2}{*}{ Model } & $\begin{array}{c}\text { Fixed } \\
\text { Effects }\end{array}$ & & 23.512 & 2.645 & -1.024 & 9.513 & & & & \\
\hline & $\begin{array}{c}\text { Random } \\
\text { Effects }\end{array}$ & & & 5.526 & -19.533 & 28.023 & & & 51.358 & 51.3577 \\
\hline
\end{tabular}

Table 1 above shows the change in average monthly number of active accounts per year and table 2 shows the same point of data but three differences specified period over the study year between 2014 to August 2020. Table 1 demonstrates that mean value of change in number of active accounts was higher at the COVID-19 pandemic period that is 27.456 lac, on the other hand mean value of change in active accounts was lower in 2020 till March that is negative value -26.003 lac. But over the study period 2014 to 2018 this value had ups and down trend. In case of risk factor, standard deviation expresses that in the pandemic period the risk factor was higher than any others period.

Table 2 also displays that the number of active accounts as well as standard deviation were higher during the pandemic period comparing with the two others specified study periods. The maximum and minimum value of active accounts comparatively favorable than two others study period. Both tables show that at the 95\% confidence level of interval the pandemic period value helps to explore the meaning that during the COVID-19 pandemic period the number of active accounts increased.

Table 3: Change in Average monthly number of registered clients per year (Amount Figure in Lac)

\begin{tabular}{|c|c|c|c|c|c|c|c|c|c|}
\hline \multirow{2}{*}{\multicolumn{2}{|c|}{ Description }} & \multicolumn{8}{|c|}{ Statistic } \\
\hline & & 2014 & 2015 & 2016 & 2017 & 2018 & 2019 & $\begin{array}{c}2020 \text { till } \\
\text { March }\end{array}$ & $\begin{array}{c}2020 \text { Apr } \\
\text { to Aug }\end{array}$ \\
\hline \multicolumn{2}{|c|}{ Mean } & 10.189 & 5.549 & 7.694 & 14.768 & 7.266 & 9.991 & 10.227 & 20.722 \\
\hline \multirow{2}{*}{$\begin{array}{l}95 \% \\
\text { Confidence } \\
\text { Interval for } \\
\text { Mean }\end{array}$} & $\begin{array}{l}\text { Lower } \\
\text { Bound }\end{array}$ & 6.648 & 1.205 & 5.105 & 1.274 & 2.958 & 4.513 & 1.490 & 2.949 \\
\hline & $\begin{array}{l}\text { Upper } \\
\text { Bound }\end{array}$ & 13.731 & 9.893 & 10.283 & 28.263 & 11.573 & 15.469 & 18.963 & 38.495 \\
\hline \multicolumn{2}{|c|}{$5 \%$ Trimmed Mean } & 10.105 & 5.638 & 7.819 & 11.993 & 6.819 & 9.900 & . & 20.724 \\
\hline \multicolumn{2}{|c|}{ Median } & 9.880 & 6.375 & 7.390 & 8.330 & 5.235 & 8.280 & 9.410 & 24.010 \\
\hline \multicolumn{2}{|c|}{ Variance } & 27.790 & 46.748 & 16.601 & 451.100 & 45.959 & 74.326 & 12.368 & 204.875 \\
\hline \multicolumn{2}{|c|}{ Std. Deviation } & 5.272 & 6.837 & 4.074 & 21.239 & 6.779 & 8.621 & 3.517 & 14.313 \\
\hline \multicolumn{2}{|c|}{ Minimum } & 3.180 & -6.160 & -1.430 & 0.290 & 0.720 & -2.310 & 7.190 & 3.640 \\
\hline \multicolumn{2}{|c|}{ Maximum } & 18.720 & 15.660 & 14.580 & 79.210 & 21.860 & 23.930 & 14.080 & 37.760 \\
\hline \multicolumn{2}{|c|}{ Range } & 15.540 & 21.820 & 16.010 & 78.920 & 21.140 & 26.240 & 6.890 & 34.120 \\
\hline \multicolumn{2}{|c|}{ Interquartile Range } & 9.700 & 9.515 & 2.865 & 6.168 & 3.908 & 16.355 & . & 27.580 \\
\hline
\end{tabular}

Note: April to August in 2020 is the COVID-19 pandemic period. Table 4:

\begin{tabular}{|c|c|c|c|c|c|c|c|c|}
\hline Data & N & Mean & $\begin{array}{c}\text { Std. } \\
\text { Deviatio }\end{array}$ & $\begin{array}{c}\text { Std. } \\
\text { Error }\end{array}$ & $\begin{array}{c}\text { 95\% Confidence Interval } \\
\text { for Mean }\end{array}$ & $\begin{array}{c}\text { Minimu } \\
\text { m }\end{array}$ & $\begin{array}{c}\text { Maximu } \\
\text { m }\end{array}$ & $\begin{array}{c}\text { Between- } \\
\text { Compone }\end{array}$ \\
\hline
\end{tabular}




\begin{tabular}{|c|c|c|c|c|c|c|c|c|c|c|}
\hline & & & & n & & $\begin{array}{l}\text { Lower } \\
\text { Bound }\end{array}$ & Upper Bound & & & $\begin{array}{c}\text { nt } \\
\text { Variance } \\
\end{array}$ \\
\hline \multicolumn{2}{|c|}{$\begin{array}{c}\text { Pre-pandemic } \\
\text { period }\end{array}$} & 44 & 9.510 & 12.306 & 1.855 & 5.769 & 13.251 & -6.160 & 79.210 & \\
\hline \multicolumn{2}{|c|}{ Pandemic period } & 5 & 20.722 & 14.313 & 6.401 & 2.949 & 38.495 & 3.640 & 37.760 & \\
\hline \multicolumn{2}{|c|}{$\begin{array}{c}\text { Previous } \\
\text { respective month } \\
\text { to pandemic } \\
\text { period }\end{array}$} & 30 & 8.918 & 6.929 & 1.265 & 6.331 & 11.505 & -4.750 & 25.620 & \\
\hline \multicolumn{2}{|c|}{ Total } & 79 & 9.995 & 10.945 & 1.231 & 7.543 & 12.446 & -6.160 & 79.210 & \\
\hline \multirow[t]{2}{*}{ Model } & $\begin{array}{l}\text { Fixed } \\
\text { Effects }\end{array}$ & & 10.713 & 1.205 & 7.594 & 12.395 & & & & \\
\hline & $\begin{array}{c}\text { Random } \\
\text { Effects }\end{array}$ & & & 2.375 & -0.225 & 20.214 & & & 9.137 & 9.13721 \\
\hline
\end{tabular}

Table 3 shows the change in average monthly number of registered clients per year and table 2 shows the same kinds of data but different three specified periods. Both tables explore that mean value of average change in monthly registered clients was higher during the COVID-19 pandemic period that is 20.7222 lac per month. At 95\% confidence interval level the value of higher bound was and 38.495 lac that was also higher than any other study period. The 5\% trimmed mean value displays the same information. The maximum value, range, interquartile range of registered clients was higher during the pandemic period that is 37.760 lac, 34.120 lac and 27.580 lac, respectively. Table 4 didn't show any different information. It also supports that during the COVID-19 pandemic period the average number of registered clients per month have increased.

Table 5: Change in Average monthly number of agents per year (Amount Figure in Lac)

\begin{tabular}{|c|c|c|c|c|c|c|c|c|c|}
\hline \multicolumn{2}{|c|}{ Description } & \multicolumn{8}{|c|}{ Statistic } \\
\hline & & 2014 & 2015 & 2016 & 2017 & 2018 & 2019 & $\begin{array}{l}2020 \text { till } \\
\text { March }\end{array}$ & $\begin{array}{c}2020 \text { Apr } \\
\text { to Aug }\end{array}$ \\
\hline \multicolumn{2}{|c|}{ Mean } & 0.302 & 0.017 & 0.124 & 0.064 & 0.083 & 0.071 & 0.070 & 0.034 \\
\hline $\begin{array}{c}95 \% \\
\text { Confidence }\end{array}$ & $\begin{array}{l}\text { Lower } \\
\text { Bound }\end{array}$ & 0.157 & -0.028 & 0.064 & -0.016 & 0.065 & 0.046 & 0.001 & -0.017 \\
\hline $\begin{array}{l}\text { Interval for } \\
\text { Mean }\end{array}$ & $\begin{array}{l}\text { Upper } \\
\text { Bound }\end{array}$ & 0.447 & 0.062 & 0.185 & 0.143 & 0.102 & 0.096 & 0.139 & 0.084 \\
\hline \multicolumn{2}{|c|}{ 5\% Trimmed Mean } & 0.315 & 0.019 & 0.125 & 0.074 & 0.086 & 0.072 & . & 0.035 \\
\hline \multicolumn{2}{|c|}{ Median } & 0.356 & 0.051 & 0.104 & 0.105 & 0.093 & 0.085 & 0.067 & 0.045 \\
\hline \multicolumn{2}{|c|}{ Variance } & 0.047 & 0.005 & 0.009 & 0.016 & 0.001 & 0.002 & 0.001 & 0.002 \\
\hline \multicolumn{2}{|c|}{ Std. Deviation } & 0.216 & 0.070 & 0.095 & 0.125 & 0.029 & 0.040 & 0.028 & 0.041 \\
\hline \multicolumn{2}{|c|}{ Minimum } & -0.174 & -0.099 & -0.073 & -0.264 & 0.010 & 0.007 & 0.044 & -0.031 \\
\hline \multicolumn{2}{|c|}{ Maximum } & 0.539 & 0.085 & 0.302 & 0.203 & 0.117 & 0.125 & 0.099 & 0.068 \\
\hline \multicolumn{2}{|c|}{ Range } & 0.713 & 0.185 & 0.376 & 0.467 & 0.107 & 0.119 & 0.055 & 0.099 \\
\hline \multicolumn{2}{|c|}{ Interquartile Range } & 0.269 & 0.137 & 0.111 & 0.116 & 0.037 & 0.074 &. & 0.071 \\
\hline
\end{tabular}

Note: April to August in 2020 is the COVID-19 pandemic period. 
Table 6:

\begin{tabular}{|c|c|c|c|c|c|c|c|c|c|c|}
\hline \multirow{2}{*}{\multicolumn{2}{|c|}{ Data }} & \multirow[t]{2}{*}{$\mathrm{N}$} & \multirow[t]{2}{*}{ Mean } & \multirow[t]{2}{*}{\begin{tabular}{c|} 
Std. \\
Deviation
\end{tabular}} & \multirow[t]{2}{*}{$\begin{array}{l}\text { Std. } \\
\text { Error }\end{array}$} & \multicolumn{2}{|c|}{$\begin{array}{l}95 \% \text { Confidence } \\
\text { Interval for Mean }\end{array}$} & \multirow[t]{2}{*}{$\begin{array}{l}\text { Minimu } \\
\mathrm{m}\end{array}$} & \multirow[t]{2}{*}{ Maximum } & \multirow{2}{*}{$\begin{array}{c}\text { Between- } \\
\text { Component } \\
\text { Variance }\end{array}$} \\
\hline & & & & & & $\begin{array}{l}\text { Lower } \\
\text { Bound }\end{array}$ & $\begin{array}{l}\text { Upper } \\
\text { Bound }\end{array}$ & & & \\
\hline \multicolumn{2}{|c|}{$\begin{array}{l}\text { Pre-pandemic } \\
\text { period }\end{array}$} & 44 & 0.092 & 0.129 & 0.019 & 0.053 & 0.131 & -0.260 & 0.490 & \\
\hline \multicolumn{2}{|c|}{ Pandemic period } & 5 & 0.034 & 0.041 & 0.018 & -0.017 & 0.084 & -0.030 & 0.070 & \\
\hline \multicolumn{2}{|c|}{$\begin{array}{c}\text { Previous } \\
\text { respective month } \\
\text { to pandemic } \\
\text { period } \\
\end{array}$} & 30 & 0.127 & 0.150 & 0.027 & 0.071 & 0.183 & -0.080 & 0.540 & \\
\hline \multicolumn{2}{|c|}{ Total } & 79 & 0.101 & 0.135 & 0.015 & 0.071 & 0.132 & -0.260 & 0.540 & \\
\hline \multirow[t]{2}{*}{ Model } & $\begin{array}{c}\text { Fixed } \\
\text { Effects }\end{array}$ & & 0.135 & 0.015 & 0.071 & 0.132 & & & & \\
\hline & $\begin{array}{c}\text { Random } \\
\text { Effects }\end{array}$ & & & 0.018 & 0.023 & 0.180 & & & 0.000 & .00023 \\
\hline
\end{tabular}

Table 5 shows the change in average monthly number of agents per year and table 6 shows the same kinds of data but three different study periods. The mean value of table 5 shows that the change of average monthly number of agents was higher in 2014 that is .302 lac and lower in 2015 that is .017 lac. During the COVID19 pandemic period the monthly average number of agents have decreased. Table 6 shows that during the previous respective month to pandemic period mean value was higher than in two other different periods. As the mean value is higher in 2014 and previous respective month to pandemic period so the risk factor is also higher during these periods. The maximum value, minimum value, range, interquartile range also support to deliver the same results. So, the researchers find that during this COVID-19 pandemic period the change in average monthly number of agents have decreased.

Table 7: Portion of Individual Transaction on Total Transaction in over the study period

\begin{tabular}{|c|c|c|c|c|c|c|c|c|}
\hline Particulars & 2014 & 2015 & 2016 & 2017 & 2018 & 2019 & $\begin{array}{c}2020 \text { Till } \\
\text { March }\end{array}$ & $\begin{array}{c}\text { Covid-19 } \\
\text { Period } \\
\text { April to } \\
\text { August) }\end{array}$ \\
\hline Inward Remittance & $0.04 \%$ & $0.02 \%$ & $0.03 \%$ & $0.03 \%$ & $0.10 \%$ & $0.07 \%$ & $0.07 \%$ & $0.31 \%$ \\
\hline Cash In transaction & $42.61 \%$ & $42.19 \%$ & $42.62 \%$ & $41.92 \%$ & $40.96 \%$ & $37.13 \%$ & $35.18 \%$ & $27.68 \%$ \\
\hline $\begin{array}{c}\text { Cash Out } \\
\text { Transaction }\end{array}$ & $37.49 \%$ & $36.55 \%$ & $38.44 \%$ & $37.99 \%$ & $37.81 \%$ & $35.47 \%$ & $32.97 \%$ & $29.95 \%$ \\
\hline P2P transaction & $17.45 \%$ & $17.67 \%$ & $14.97 \%$ & $14.90 \%$ & $15.60 \%$ & $20.49 \%$ & $24.13 \%$ & $29.64 \%$ \\
\hline $\begin{array}{c}\text { Salary Disbursement } \\
\text { (B2P) }\end{array}$ & $0.57 \%$ & $0.82 \%$ & $1.05 \%$ & $1.45 \%$ & $1.77 \%$ & $2.35 \%$ & $2.77 \%$ & $5.01 \%$ \\
\hline $\begin{array}{c}\text { Utility Bill Payment } \\
\text { (P2B) }\end{array}$ & $1.11 \%$ & $0.92 \%$ & $0.97 \%$ & $0.80 \%$ & $0.88 \%$ & $1.16 \%$ & $1.09 \%$ & $1.62 \%$ \\
\hline Merchant Payment & $0.00 \%$ & & $0.00 \%$ & $0.46 \%$ & $0.79 \%$ & $1.26 \%$ & $1.37 \%$ & $1.64 \%$ \\
\hline $\begin{array}{c}\text { Government } \\
\text { Payment }\end{array}$ & & & & & & & & \\
\hline Others & $0.75 \%$ & $1.81 \%$ & $1.92 \%$ & $1.73 \%$ & $1.47 \%$ & $1.63 \%$ & $1.96 \%$ & $3.14 \%$ \\
\hline Total & $100 \%$ & $100 \%$ & $100 \%$ & $100 \%$ & $100 \%$ & $100 \%$ & $100 \%$ & $100 \%$ \\
\hline
\end{tabular}

Source: Bangladesh Bank 
Table 7 shows $t$ the proportion of individual transaction over the study period. The authors mainly focus on the COVID-19 pandemic period. During the COVID-19 pandemic period, cash in and cash out have declined to $27.68 \%$ and $29.95 \%$ compared with the pre-pandemic period. The data shows that study period 2014 till March of 2020 proportion of cash in and cash out are more than the current period of COVID-19. This situation happened because of lockdown of the country. The general public cannot move outside from their house and all the outlets have closed down this moment. But in case of inward remittance $(0.31 \%), \mathrm{p} 2 \mathrm{p}$ transaction (29.64\%), salary disbursement (5.01\%), utility bill payment (1.62\%), merchant payment (1.64\%), government payment $(1.02 \%)$ and other types of mobile banking transactions $(3.14 \%)$ proportion compared with the pre-covid-19 period have increased. At the time of lockdown of the country government or private sector employees, foreigner, bank's customers and general public felt uneasy when visiting banks for the purpose of $r$ making transactions: that's why most of them used mobile banking staying at their home and obviously mobile banking is a comfortable tool for executing receipt and payment of money setting at the home.

Table 8: \% of Individual Transaction on Total Transaction during the Pandemic Period and Pre-pandemic Period

\begin{tabular}{|l|c|c|c|}
\hline \multicolumn{1}{|c|}{ Particulars } & Pandemic Period & Pre-pandemic Period & Deviation \\
\hline Inward Remittance & $0.31 \%$ & $0.05 \%$ & $0.26 \%$ \\
\hline Cash In transaction & $27.89 \%$ & $40.37 \%$ & $-12.48 \%$ \\
\hline Cash Out Transaction & $29.83 \%$ & $36.67 \%$ & $-6.84 \%$ \\
\hline P2P transaction & $29.96 \%$ & $17.89 \%$ & $12.07 \%$ \\
\hline Salary Disbursement (B2P) & $4.70 \%$ & $1.54 \%$ & $3.16 \%$ \\
\hline Utility Bill Payment (P2B) & $1.60 \%$ & $0.99 \%$ & $0.61 \%$ \\
\hline Merchant Payment & $1.59 \%$ & $0.65 \%$ & $0.94 \%$ \\
\hline Government Payment & $0.89 \%$ & $0.37 \%$ & $0.52 \%$ \\
\hline Others & $3.22 \%$ & $1.61 \%$ & $1.61 \%$ \\
\hline
\end{tabular}

\section{Source: Bangladesh Bank}

Table 8 shows the proportion of individual transactions on total transactions during the pandemic period and pre-pandemic period and differences between them. The authors find that during the COVID-19 pandemic period the cash in transactions and cash out transactions have declined from $40.37 \%$ to $27.89 \%$ and $36.67 \%$ to $29.83 \%$ respectively. On the other hand, inward remittance is increased $.05 \%$ to $0.31 \%$, P2P transaction is increased $17.89 \%$ to $29.96 \%$, salary disbursement (B2P) is increased $1.54 \%$ to $4.70 \%$, utility bill payment (P2B) is increased $0.99 \%$ to $1.60 \%$, merchant payment is increased $0.65 \%$ to $1.59 \%$, government payment is increased $0.37 \%$ to $.89 \%$ and others transaction is increased $1.61 \%$ to $3.22 \%$ respectively. 


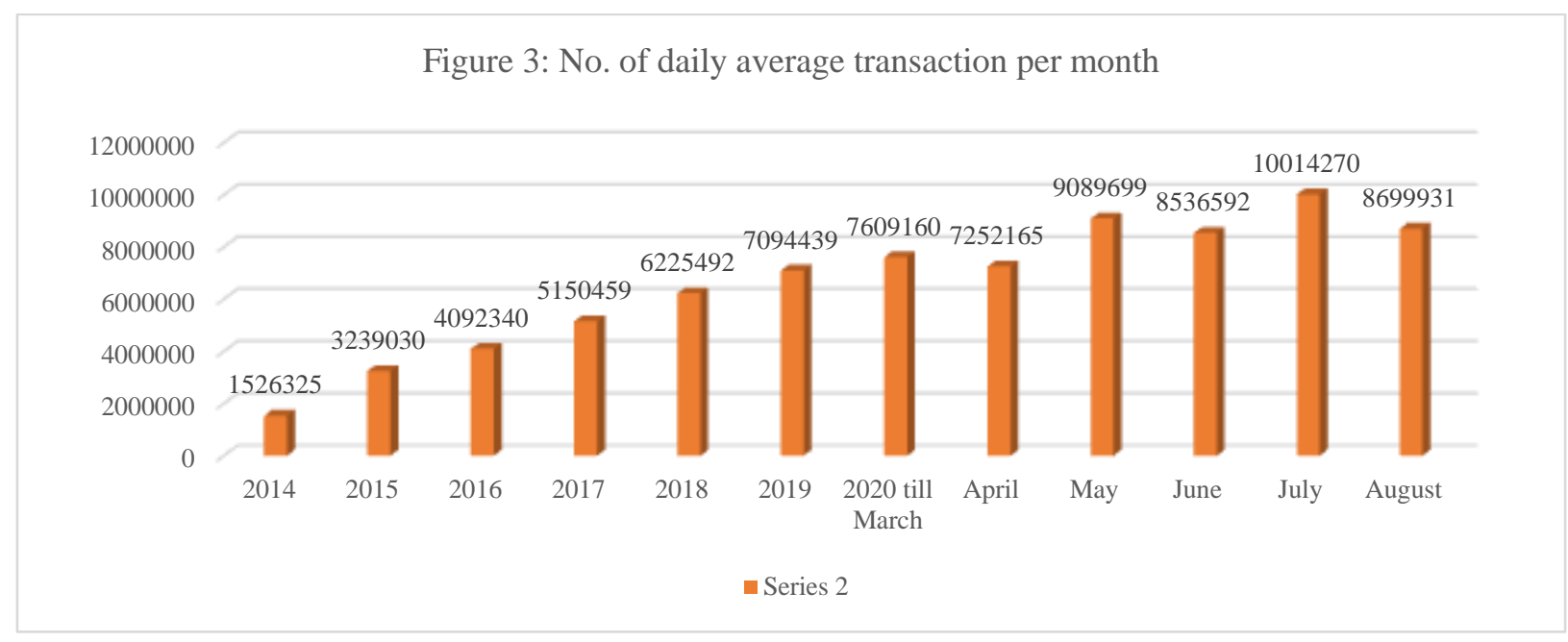

Figure 3 shows the $t$ no. of daily average transactions per month over the study period. At the earlier stage of mobile banking in 2014 the number of daily average transactions per month was 15,26,325 and year by year this figure has sequentially increased. In the year of 2019 this figure was 70,94,439 and in 2020 till March it was 76,09,160 but during the COVID-19 pandemic period this figure experienced an up and down trend. . This graph shows that in April 2020 the number of daily average transaction per month was $72,52,165$ and accordingly it increased to $90,89,699$ in May 2020 but in June, July, August it was ups \& down figure that was $85,36,592,1,00,14,270$ and $86,999,31$.

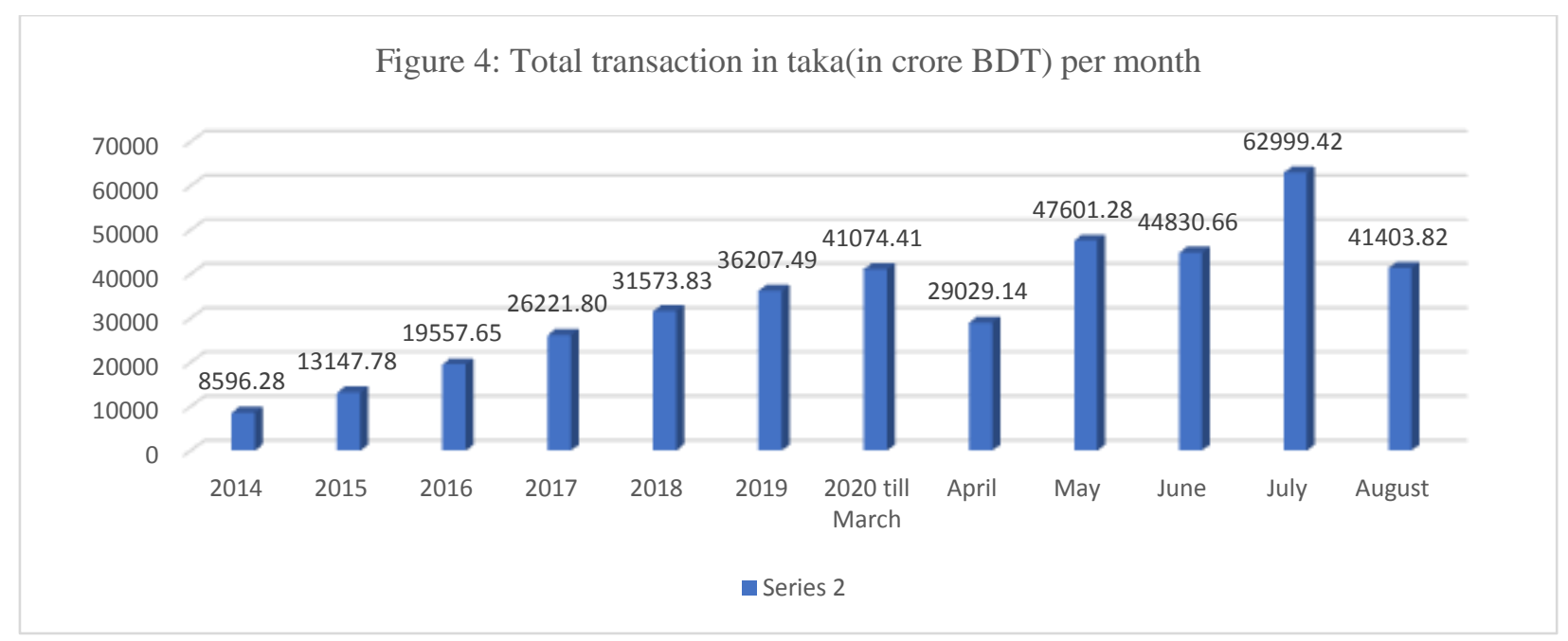

Figure 4 shows the average total transactions per month during the study period, both the pandemic period of COVID-19 and the pre-pandemic period. From 2014 to March of 2020 this figure has increased, in 2014 the amount of average monthly transactions was 8596.28 cores and sequentially in 2019 was 36,207.49 cores and in 2020 till March was 41,074.41 cores. The earlier stage of COVID-19 pandemic period, the amount of average monthly transactions was very low that was 29,029.14 cores because of Coronavirus fairness among the people and lockdown of the whole country but after beginning of the lockdown day by day the situation was recovering and it impacted on mobile banking transactions. The above figure shows that in July during the COVID-19 period the average monthly transactions was higher than any others month of the whole study period that was 62,999.42 cores but in August 2020 it declined in 41,403.82 cores. The amount of average transaction per month during the pandemic period was up and down. 
H1: There is a significant difference between changes in the numbers of active accounts among prepandemic period, pandemic period and previous respective months to pandemic period of COVID-19.

ANOVA Test (Changes in the Number of Active Accounts)

\begin{tabular}{|c|c|c|c|c|c|c|}
\hline Data & Sum of Squares & Degree of Freedom & Mean Square & F & Sig. & $\begin{array}{c}\text { Table Value } \\
\text { at 5\% sig. } \\
\text { Level }\end{array}$ \\
\cline { 1 - 5 } Between Groups & 3302.921 & 2 & 1651.461 & 2.987 & .000 & 3.11698 \\
\hline Within Groups & 42012.456 & 76 & 552.795 & & & \\
\hline Total & 45315.377 & 78 & & & & \\
\hline
\end{tabular}

Above, the ANOVA table shows the variance analysis (F-test) of changes in the number of active accounts of mobile banking over the study period, from the pre-pandemic period of COVID-19, pandemic period and previous respective months to pandemic period from 2014 to August 2020. It demonstrates that the actual value of $\mathrm{F}$ is 2.987 which is lower than the table value of $\mathrm{F}(3.11698)$ at $5 \%$ level of significance, so null hypothesis is sufficient to be accepted. The authors find that from this hypothesis, there is no significant difference among the pre-pandemic period of COVID-19, pandemic period and previous respective months to pandemic period of number of mobile banking active accounts over the study period.

$\mathrm{H} 2$ : There is a significant difference between changes in the numbers of registered clients among prepandemic period, pandemic period and previous respective months to pandemic period of COVID-19.

ANOVA Test (Changes in the Number of registered clients)

\begin{tabular}{|c|c|c|c|c|c|c|}
\hline Data & Sum of Squares & Degree of Freedom & Mean Square & F & Sig. & $\begin{array}{c}\text { Table Value } \\
\text { at 5\% sig. } \\
\text { Level }\end{array}$ \\
\hline Between Groups & 620.490 & 2 & 310.245 & 2.703 & .000 & 3.11698 \\
\cline { 1 - 4 } Within Groups & 8723.145 & 76 & 114.778 & & & \\
\hline Total & 9343.636 & 78 & & & & \\
\hline
\end{tabular}

From the above ANOVA test, the authors try to display the variance analysis (F-test) of changes in the number of registered clients of mobile banking over the study period at pre-pandemic period of COVID-19, pandemic period and previous respective months to pandemic period from 2014 to August 2020. This table shows that the calculated value of $\mathrm{F}$ (2.703) is lower than table value of $\mathrm{F}$ (3.11698) at 5\% significant level, which means it lies on the confidence level so null hypothesis is accepted. The researchers find here there is no significant difference among the pre-pandemic period of COVID-19, pandemic period, and previous respective months to pandemic period of number of mobile banking registered clients over the study period.

H3: There is a significant difference between changes in the numbers of agents among pre-pandemic period, pandemic period and previous respective months to pandemic period of COVID-19.

ANOVA Test (Changes in the Number of Agents)

\begin{tabular}{|c|c|c|c|c|c|c|}
\hline Data & Sum of Squares & Degree of Freedom & Mean Square & $\mathbf{F}$ & Sig. & $\begin{array}{c}\text { Table Value } \\
\text { at } 5 \% \text { sig. } \\
\text { Level }\end{array}$ \\
\hline Between Groups & .046 & 2 & .023 & \multirow[t]{2}{*}{1.267} & \multirow[t]{2}{*}{.000} & \multirow[t]{2}{*}{3.11698} \\
\hline Within Groups & 1.375 & 76 & .018 & & & \\
\hline
\end{tabular}




\begin{tabular}{|l|l|l|l|l|l|l|}
\hline Total & 1.421 & 78 & & & & \\
\hline
\end{tabular}

The above table shows the ANOVA analysis of changes in the number of agents of mobile banking over the study period at pre-pandemic period of COVID-19, pandemic period and previous respective months to pandemic period from 2014 to August 2020. It demonstrates the table value of $\mathrm{F}$ (3.11698) is higher than calculated value of $\mathrm{F}(1.267)$ at $5 \%$ level of significance, so null hypothesis cannot be rejected. Therefore, the authors find that there is no significant difference among the pre-pandemic period of COVID-19, pandemic period and previous respective months to pandemic period of number of mobile banking agents over the study period.

Above, the hypothesis analysis of $\mathrm{H} 1, \mathrm{H} 2$ and $\mathrm{H} 3$ expresses no significant difference among the prepandemic period of COVID-19, pandemic period and previous respective months to pandemic period of number of mobile banking changes of active accounts, changes of registered clients and changes of agents over the study period. Therefore, the researchers try to analyse any differences between the pre-pandemic period of COVID-19 and pandemic period of COVID-19. So, two sample T-test are analyzed below in order to check the changes of active accounts, changes of registered clients and changes of agents of mobile banking have increased during the COVID-19 period or not.

H4: The changes in the number of active customers are increased during the COVID-19 pandemic period.

T-test (Number of Active Accounts)

\begin{tabular}{|c|c|c|c|c|c|c|c|c|c|}
\hline & \multicolumn{8}{|c|}{ t-test for Equality of Means } \\
\hline & & \multirow[t]{2}{*}{$\mathrm{t}$} & \multirow[t]{2}{*}{ df } & \multirow[t]{2}{*}{$\begin{array}{l}\text { Sig. (2- } \\
\text { tailed) }\end{array}$} & \multirow[t]{2}{*}{$\begin{array}{c}\text { Table value at } \\
5 \% \text { sig. level }\end{array}$} & \multirow[t]{2}{*}{$\begin{array}{c}\text { Mean } \\
\text { Difference }\end{array}$} & \multirow[t]{2}{*}{$\begin{array}{l}\text { Std. Error } \\
\text { Difference }\end{array}$} & \multicolumn{2}{|c|}{$\begin{array}{l}\text { 95\% Confidence } \\
\text { Interval of the } \\
\text { Difference }\end{array}$} \\
\hline & & & & & & & & Lower & Lower \\
\hline \multirow{2}{*}{ 营 } & $\begin{array}{c}\text { Equal } \\
\text { variances } \\
\text { assumed }\end{array}$ & -2.284 & 77 & .000 & $+/-1.9913$ & -24.7795 & 10.848 & -46.381 & -3.178 \\
\hline & $\begin{array}{c}\text { Equal } \\
\text { variances not } \\
\text { assumed }\end{array}$ & -1.559 & 4.229 & .000 & & -24.7795 & 15.896 & -67.987 & 18.428 \\
\hline
\end{tabular}

Above the T-statistic table shows that the actual value of T (-2.284) is more than the critical (Table) value $(+/-1.9913)$ that's why it is not sufficient to accept the null hypothesis. So, this hypothesis expresses that the number of active accounts of mobile banking have increased during the COVID-19 pandemic period comparing with the pre-pandemic period of COVID-19. It means during the pandemic period the number of active accounts is more than before from January 2014.

H6: The changes in the numbers of agents are increased during the COVID-19 pandemic period.

T-test (Number of Agents)

\begin{tabular}{|c|c|c|c|c|c|c|c|c|c|}
\hline & \multicolumn{8}{|c|}{ t-test for Equality of Means } \\
\hline & & \multirow[t]{2}{*}{$\mathbf{t}$} & \multirow[t]{2}{*}{ df } & \multirow[t]{2}{*}{$\begin{array}{l}\text { Sig. (2- } \\
\text { tailed) }\end{array}$} & \multirow[t]{2}{*}{$\begin{array}{c}\text { Table value at } \\
5 \% \text { sig. level }\end{array}$} & \multirow[t]{2}{*}{$\begin{array}{c}\text { Mean } \\
\text { Difference }\end{array}$} & \multirow[t]{2}{*}{$\begin{array}{l}\text { Std. Error } \\
\text { Difference }\end{array}$} & \multicolumn{2}{|c|}{$\begin{array}{l}\text { 95\% Confidence } \\
\text { Interval of the } \\
\text { Difference }\end{array}$} \\
\hline & & & & & & & & Lower & Lower \\
\hline 苟 & $\begin{array}{c}\text { Equal } \\
\text { variances }\end{array}$ & 1.164 & 77 & .000 & $\begin{array}{c}+/- \\
1.9913\end{array}$ & .07242 & .06222 & -.05148 & .19633 \\
\hline
\end{tabular}

Acc. Fin. Review 6(1) 54- 68 (2021) 


\begin{tabular}{|c|c|c|c|c|c|c|c|c|c|}
\hline assumed & & & & & & & & & \\
\hline $\begin{array}{c}\text { Equal } \\
\text { variances not } \\
\text { assumed }\end{array}$ & 2.993 & 12.312 & .000 & & .07242 & .02420 & .01985 & .12500 \\
\hline
\end{tabular}

From the above T-statistic table the researchers find that actual value of $\mathrm{T}$ is 1.164 that is less than the table value of $\mathrm{T}(+/-1.9913)$ at the $5 \%$ level of significance. So, the research value stays on the confidence level that's why null hypothesis is accepted. It belongs to the meaning that the number of agents of mobile banking haven't increased during the pandemic period of COVID-19 compared with the pre-pandemic period. So, during the COVID-19 period the number of agents is decreased.

H5: The changes in the numbers of clients are increased during the COVID-19 pandemic period.

T-test (Number of Registered Clients)

\begin{tabular}{|c|c|c|c|c|c|c|c|c|c|}
\hline & \multicolumn{8}{|c|}{ t-test for Equality of Means } \\
\hline & & \multirow[t]{2}{*}{$\mathrm{t}$} & \multirow[t]{2}{*}{ df } & \multirow[t]{2}{*}{$\begin{array}{l}\text { Sig. (2- } \\
\text { tailed) }\end{array}$} & \multirow[t]{2}{*}{$\begin{array}{c}\text { Table value at } \\
5 \% \text { sig. level }\end{array}$} & \multirow[t]{2}{*}{$\begin{array}{c}\text { Mean } \\
\text { Difference }\end{array}$} & \multirow[t]{2}{*}{$\begin{array}{l}\text { Std. Error } \\
\text { Difference }\end{array}$} & \multicolumn{2}{|c|}{$\begin{array}{l}95 \% \text { Confidence } \\
\text { Interval of the } \\
\text { Difference }\end{array}$} \\
\hline & & & & & & & & Lower & Lower \\
\hline \multirow{2}{*}{ صَّ } & $\begin{array}{c}\text { Equal } \\
\text { variances } \\
\text { assumed }\end{array}$ & -2.328 & 77 & .000 & $+/-1.9913$ & -11.4520 & 4.9199359 & -21.2488 & -1.65516 \\
\hline & $\begin{array}{c}\text { Equal } \\
\text { variances not } \\
\text { assumed }\end{array}$ & -1.758 & 4.291 & .000 & & -11.4520 & 6.5145481 & -29.0661 & 6.16211 \\
\hline
\end{tabular}

The above table shows the $\mathrm{T}$ statistic table of number of registered clients of mobile bank from the study period 2014 to august 2020. The authors find that from this table actual $\mathrm{T}$ value $(-2.328)$ is more than acceptance region (Table value $+/-1.9913$ ). As the actual value is situated at the significant level, so null hypothesis is rejected. It provides the result that the number of registered clients of mobile banking have increased during the pandemic period of COVID-19 comparing with the pre-pandemic period of COVID-19.

\section{Discussion}

The authors find various undisclosed things regarding the mobile banking performance during the COVID-19 pandemic period compared with the pre-pandemic period. In case of change in average monthly number of active accounts and change in average monthly number of registered clients are increased during the COVID-19 period but the change in average monthly number of agents has declined during this period. The proportion of mobile banking individual transaction explore that except cash in \& cash out, all others individual transactions like inward remittance, P2P transaction, salary disbursement (B2P, utility bill payment, merchant payment, government payment and other types of transaction rate are increased during the COVID-19 pandemic period. This paper also finds that number of daily average transaction per month are comparatively higher during the COVID-19 period than pre-pandemic period, the total transaction in Taka per month gets ups \& down trend during this COVID-19 period but some months in COVID-19 period total transactions amounts are higher than pre-pandemic period average monthly total transactions. The authors revel by using hypothesis analysis that in case of F-test explores there is no significant differences in 
the changes of number of active accounts, changes of number of registered clients and changes of number of agents among the pre-pandemic period of COVID-19, pandemic period. and previous respective month to pandemic period of the study year. The T-test discloses that during the COVID-19 pandemic period the number of active accounts, number of registered client's rate are increased and on the other hand the number of agents rate didn't increased during this COVID-19 period.

\section{Conclusion}

The purpose for which this research paper is drafted is fully demonstrated by the above result. The result implies that during the COVID-19 pandemic period mobile banking has extended its scope to help people collect, transfer, pay in a house setting whether they were living in a rural or urban area. At the lockdown situation of whole country people can't go outside for their daily financial transactions but they are doing all these things by mobile banking at home. The average change in number of active accounts \& registered clients are disclosing that during this COVID-19 period people feel pleasure \& interested to create mobile banking account for getting banking services. In case of inward remittance, P2P transaction, salary disbursement (B2P, utility bill payment, merchant payment, government payment and other types of transactions rate of mobile banking, the customers of mobile banking get all the services from their house except cash in \& cash out, because lockdown country area and general fear about CORONA virus affect it negatively which has been confirmed in this paper. All the result of this paper will knock the authority of mobile banking to furnish their cash in \& cash out facilities in such way so that the customer of mobile banking can get facilities of cash in \& cash out at home, the author of this paper is thinking that will it be possible to provide door to door mobile banking services like Food Panda or other types of home delivery services provider system?

\section{References}

G., S., V, S., Sathish. M, T., \& A.V, C. (2020, August). Impact Of Covid-19 Outbreak in Digital Payments. International Journal for Innovative Research in Multidisciplinary Field, 6(8), 159-164.

Abuga, I. M., \& Manyange, M. N. (2015). Effectiveness of mobile banking services in selected commercial banks in Rwanda. Journal of Applied Economics and Business, 3(2), 49-60.

Al-Husein, M., \& Sadi, M. A. (2015). Preference on the Perception of Mobile Banking: A Saudi Arabian Perspective. European Online Journal of Natural and Social Sciences, 4(1), 161-172.

Arifin. (2018). No 主観的健康感を中心とした在宅高齢者における 健康関連指標に関する共分散構造分析Title. Journal of Materials Processing Technology, 1(1), 1-8. http://dx.doi.org/10.1016/j.cirp.2016.06.001\%0Ahttp://dx.doi.org/10.1016/j.powtec.2016.12.055\%0Ahttps://doi.o rg/10.1016/j.ijfatigue.2019.02.006\%0Ahttps://doi.org/10.1016/j.matlet.2019.04.024\%0Ahttps://doi.org/10.1016/j. matlet.2019.127252\%0Ahttp://dx.doi.o

Atieno, A. (2018). Mobile banking and organizational performance in the banking industry. Journal of Scientific Research and Studies, 5(5), 121-135. http://www.modernrespub.org/jsrs/index.htm

Bach, M. P., Starešinić, B., Omazić, M. A., Aleksić, A., \& Seljan, S. (2020). m-Banking quality and bank reputation. Sustainability (Switzerland), 12(10), 1-18. https://doi.org/10.3390/su12104315

Bidarra, S., \& Henrique, S. (2013). www.econstor.eu.

Hossain, A., \& Haque, Z. (2014). Prospects and challenges of mobile banking in Bangladesh. Journal of Business Studies, $X X X V(2), 165-186$.

Chuchuen, C. (2016). The perception of mobile banking adoption: the study of behavioral, security, and trust in Thailand. international Journal of social science and Humanity, 6(7), 547.

Iyar, L. (2020, September 22). Mobile Banking Is on The Rise Due to COVID-19 -- But Something's Lacking from Most Bank Apps.

Kato, G. K., Otuya, W. I., Owunza, J. D. Nato, J. A. (2015). Research Article Mobile Banking and Performance of Commercial Banks in Kenya. International Journal of Current Research, 6(12), 10670-10674.

Khan, S. N., Akter, M., \& Paul, T. (2016). Factors influencing adoption and usage of mobile banking: Bangladesh experience. In The 5th Asian management research and case conference. Springer (pp. 16-18). 
Krishna Kishore, S. V., \& Sequeira, A. H. (2016). An empirical investigation on mobile banking service adoption in rural Karnataka. SAGE Open, 6(1), 1-21. https://doi.org/10.1177/2158244016633731

Muiruri, K. (2015). Role of Mobile Banking in Enhancing Financial Performance of Micro and Small Enterprises in Kenya : a Case Study of Nakuru Town. International Journal of Economics, Commerce and Management, 3(10), 604-618.

Rehman, Z. U., \& Shaikh, F. A. (2020). Critical Factors Influencing the Behavioral Intention of Consumers towards Mobile Banking in Malaysia. Engineering, Technology \& Applied Science Research, 10(1), 5265-5269. https://doi.org/10.48084/etasr.3320

Report, T. (2020, June 10). Covid-19: SIBL urges clients to use mobile app for safer banking. Retrieved from The

Business Standard:

Sagib, G. K., \& Zapan, B. (2014). Bangladeshi mobile banking service quality and customer satisfaction and loyalty. Management and Marketing, 9(3), 331-346.

Saleem, Z., \& Rashid, K. (2011). Relationship between Customer Satisfaction and Mobile Banking Adoption in Pakistan. International Journal of Trade, Economics and Finance, 2(6), 537-543. https://doi.org/10.7763/ijtef.2011.v2.162

Shuhidan, S. M., Hamidi, S. R., \& Saleh, I. S. (2017). Perceived Risk towards Mobile Banking: A case study of Malaysia Young Adulthood. IOP Conference Series: Materials Science and Engineering, 226(1). https://doi.org/10.1088/1757-899X/226/1/012115

Siddik, M. N. A., Sun, G., Kabiraj, S., Shanmugan, J., \& Yanjuan, C. (2016). Impacts of e-banking on performance of banks in a developing economy: empirical evidence from Bangladesh. Journal of Business Economics and Management, 17(6), 1066-1080. https://doi.org/10.3846/16111699.2015.1068219

Skalska, C. (2020, May 20). Mobile banking in the era of COVID-19

Tafese, G., \& Desta, D. (2014). The Roles of Civics and Ethical Education in Shaping Attitude of the Students in Higher Education: The Case of Mekelle University. International Journal of Scientific and Research Publications, 4(10), 680-683.

Too, V. K., Ayuma, D. C., \& Ambrose, D. K. (2016). Effects of Mobile Banking on the Financial Performance of Commercial Banks in Kapsabet (Kenya): A Case of Selected Banks in Kapsabet Town. IOSR Journal of Business and Management (IOSR-JBM), 18(10), 37-48. https://doi.org/10.9790/487X-1810063748 